Emir. J. Agric. Sci. 2004. 16 (2): 01-08

http://www.cfs.uaeu.ac.ae/research/ejas.html

\title{
Phytotoxicity of cadmium and its effect on two genotypes of Brassica juncea L.
}

\author{
Indira Chaturvedi
}

\author{
C.M.D. Post Graduate, College, Bilaspur, Chhattisgarh, 495001 INDIA
}

\begin{abstract}
By using two Brassica juncea, L. (Indian mustard) genotypes (Varuna and DHR-9504) a greenhouse experiment was carried out to study the effect of cadmium (Cd) on growth, yield and concentration of cadmium $(\mathrm{Cd})$ in different plant parts at the Agricultural Research Station, Bilaspur Chhattisgarh, India during 2002-2003. Plants were grown under controlled climatic conditions and subjected to increasing Cd supply in the form of CdCl2 @ 0, 20, 40, 60, 80 and $100 \mathrm{mg} \mathrm{Cd} \mathrm{kg}^{-1}$ soil. Cd phytotoxicity was shown by growth retardation of Varuna and DHR-9504. Varuna showed greater sensitivity to Cd toxicity than DHR-9504. Increasing Cd supply markedly reduced the seed, stem and root dry weight of both genotypes (Varuna and DHR-9504), and these decreases were more marked in Varuna. Due to increased level of $\mathrm{Cd}$ application, the $\mathrm{Cd}$ concentration increased significantly in various plant parts in both the Brassica genotypes tested. Increase in Cd concentration of about 5 times in seeds, 7 times in stems and 9 times in roots was noted with an application of $20 \mathrm{mg} \mathrm{Cd} \mathrm{kg}^{-1}$ soil more than the control. Cd was accumulated in the roots in much higher amounts than in the stem and seeds, especially in the case of DHR-9504, indicating that there is limited transport of $\mathrm{Cd}$ from the root system to the above ground plant parts in DHR-9504 genotype due to the presence of strong Cd-binding proteins in the roots. Genotype DHR-9504 had significantly less uptake of Cd than genotype Varuna. More data are needed to ascertain the findings of this study.
\end{abstract}

Key words: Brassica genotypes, cadmium, Cd-binding protein, growth retardation, phytotoxicity.

\section{عسمية عنصر الكانيوم وتأثيرها عل صفينمن نبلت الخرل الهني Brassica juncea, $\mathrm{L}$}

\author{
إنیيراجلتوفيي \\ كلية الررلسلت الهليا، بيلانبور،جانيسجار، الهند
}

ملخص: لجريت تجربة في البيوت الزجلجية لدرلسة تأثير الكاديوم على نمو ومحصول صفين من نبلت الخرل الهز دي (Varuna - DHR 9504)

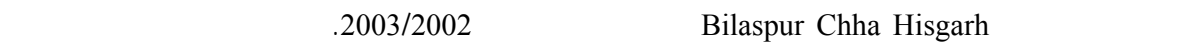

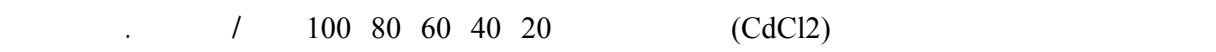

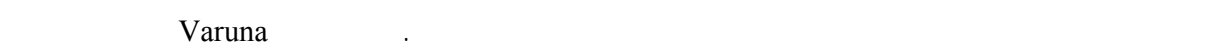

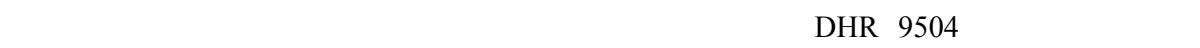

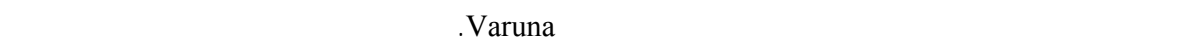
تركيز الكاديوم في لجزاء النبت زاد زيادة معنوية في كلا الصفين، حيث زاد التركيز خهس مرات في البذور وسع فمرات

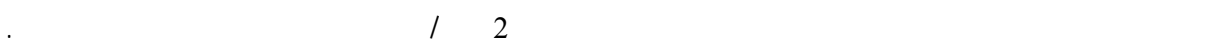

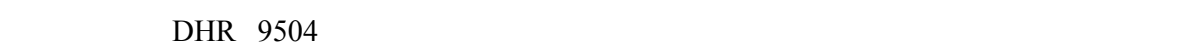

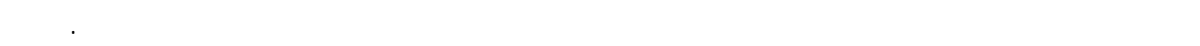

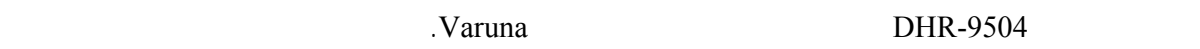




\section{Introduction}

Brassica juncea L. (Indian mustard) is an important oilseed crop of India and is quite sensitive to cadmium. This species originates from the hybridization of Brassica nigra and Brassica campestris which probably happened in South Western Asia and India where the natural distribution of the two species overlaps (Sauer, 1993). Brassica juncea L. has been identified as a high biomass-producing crop with the capacity to take up and accumulate heavy metals such as $\mathrm{Cd}, \mathrm{Cu}, \mathrm{Ni}, \mathrm{Zn}$ and $\mathrm{Pb}$ (Kumar et al., 1995). Brassica juncea L. is able to accumulate more than $400 \mu \mathrm{g} \mathrm{Cd} \mathrm{g}^{-1}$ in the shoots, a physiological trait which may be exploited for the bioremediation of contaminated soils and waters (Haag-Kerwer at al., 1999). Oilseed crops are generally grown in submarginal land under rainfed as well as irrigated conditions. Deshveer and Singh (2003) stated that the yield level of Indian mustard crop is of low magnitude, despite the use of $\mathrm{N}$ and $\mathrm{P}$ fertilizers. Foy et al. (1978) and Sheoran et al. (1991) found that indiscriminate usage of phosphatic fertilizers in agricultural fields leads to build up cadmium level in the soil which affects plant growth and economic yield.

Heavy metals constitute an important group of environmental pollutants, as these are non-biodegradable and are readily taken up by the plants. Among an array of heavy metal pollutants, $\mathrm{Cd}$ is of the major concern. Cadmium is one of the most toxic nonessential and mobile metallic elements found in soils, and it affects plant growth adversely. Nriagu and Pacgana (1988) reported that about 22000 tonnes of cadmium is globally discharged every year in to the soil. Cadmium contamination of the soils is regarded as a great danger for living organisms, because its concentration in top soils continuously increases and its surface flux from aerosols is greater than the losses by leaching and plant uptake (KabataPendias and Pendias, 1989; Fergusson, 1991). The flux of $\mathrm{Cd}$ from the soil solution into the roots of plants occurs by passive diffusion or by active transfer (Cataldo et al., 1983; Clarkson and Lutge, 1989).

Cadium is easily taken up by plants and translocated to different plant parts. Patterson (1977) reported that plant species and even genotypes differ greatly in their ability to take up, transport and accumulate $\mathrm{Cd}$ within the plant. Many of the metal accumulating plants are members of the Brassica family. Generally, visible toxicity symptoms and impaired growth occur only at relatively high internal $\mathrm{Cd}$ concentrations (Adriano, 1986). Muramoto et al. (1990) reported that root and shoot weights of rice were reduced $32 \%$ and $21 \%$ by $100 \mathrm{mg} \mathrm{Cd}$ kg-1. Florijn and Van Beusichem (1993) found that internal distribution rather than uptake caused genotypic differences in shoot $\mathrm{Cd}$ concentration of maize inbred lines. The objective of the present study was to investigate the effect of $\mathrm{Cd}$ on growth, yield and distribution of $\mathrm{Cd}$ in different plant parts among two Brassica juncea, L. genotypes.

\section{Materials and Methods}

The experiment was carried out with two genotypes of Brassica juncea, L. (Varuna and DHR-9504) at the Agricultural Research Station, Bilaspur Chhattisgarh, India during 2002-2003. The plants were grown in a greenhouse under controlled environmental conditions (temperature $27^{\circ} \mathrm{C}$, and humidity $50-60 \%$ ).

Physico-chemical properties of the soil were measured by the standard methods of soil chemical analysis (NIAST, 1988). The soil had $0.68 \%$ organic carbon, $240.3 \mathrm{~kg}$ $\mathrm{ha}^{-1}$ nitrogen, $194 \mathrm{~kg} \mathrm{ha}^{-1} \mathrm{~K}_{2} \mathrm{O}$ and $\mathrm{Zn}, \mathrm{B}$ and 
Mo $0.70,0.31$ and $0.04 \mathrm{mg} \mathrm{kg}{ }^{-1}$ soil respectively, available sulphate-sulphur 9.1 $\mathrm{mg} \mathrm{kg}{ }^{-1}$ soil, available $\mathrm{P} 24.5 \mathrm{mg} \mathrm{kg} \mathrm{mg}^{-1}$ soil and $0.40 \mathrm{mg} \mathrm{Cd} \mathrm{kg}{ }^{-1}$ soil with $p \mathrm{H}$ 7.85. 50 earthenware pots of $10 \mathrm{~kg}$ capacity having hole at their bottom were used for each replicate. The air-dry soil was sieved $(<2 \mathrm{~mm})$ and $8 \mathrm{~kg}$ soil was placed in each pot. N (urea)@100 kg ha ${ }^{-1}$, P (single superphosphate, diammonium phosphate)@ $30 \mathrm{~kg} \mathrm{ha}{ }^{-1}, \mathrm{~K}$ (muriate of potash)@35 kg $\mathrm{ha}^{-1}$ and farmyard manure @ 25 tonnes ha ${ }^{-1}$ were applied as basal recommended fertilizers, along with $\mathrm{Cd}$ in the form of $\mathrm{CdCl}_{2} @$ 0, 20,40,60,80 and $100 \mathrm{mg} \mathrm{Cd}$ $\mathrm{kg}^{-1}$ soil.

Each treatment was replicated three times, and the cd was mixed thoroughly with the soil and applied at the time of sowing. The water used for preparing the nutrient solution was deionized. Seeds of two genotypes of Brassica juncea L. (Varuna and DHR-9504) were sown in each pot on 12 November, 2002. After germination, the seedlings were thinned to four plants per pot and grown to maturity. Deionized water was used for irrigating the crop as and when required. At harvest on 17 March, 2003, the roots, stems and seeds were separated and dried at $70^{\circ} \mathrm{C}$ in order to determine dry weight and $\mathrm{Cd}$ concentration. Total content of $\mathrm{Cd}$ in plants was assayed by ICP after wet-acid (HNO3: H2SO4: HClO4=10:1:4) digestion (NIAST, 1988). Treatments were randomized throughout the greenhouse and the results given in the tables and figures are the means from three independent replications. The results were statistically analyzed by Duncan's test at a 5\% probability level.

\section{Results}

Cd phytotoxicity was shown by growth retardation of Varuna and DHR9504. The growth of Varuna and DHR-9504 was significantly reduced at the $0-20 \mathrm{mg} \mathrm{kg}$ 1 and $20-40 \mathrm{mg} \mathrm{kg}^{-1}$ of $\mathrm{Cd}$ treated soil, respectively (Figure 1A, 1B). An increasing supply of $\mathrm{Cd}$ resulted in significant decreases in the stem and root growth of both genotypes (Figure 1A, 1B). The decreases were more distinct in the Varuna genotype. For example, with a $20 \mathrm{mg} \mathrm{kg}^{-1}$ Cd supply, stem dry weight was reduced by around $15 \%$ in DHR-9504 and $35 \%$ in Varuna. Similar decreases were also noted for root dry weight (Figure 1A, 1B). Seed yield of Brassica genotypes (Varuna and DHR-9504) decreased to a greater extent than that of other plant parts, there was a significant reduction in yield of about $45 \%$ and $25 \%$ for seed at $100 \mathrm{mg} \mathrm{Cd} \mathrm{kg}^{-1}$ soil compared with the control in genotypes Varuna and DHR-9504 respectively (Figure 2). 


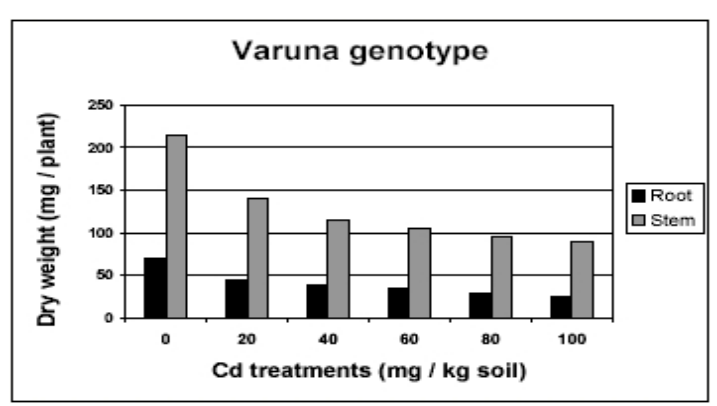

(A)

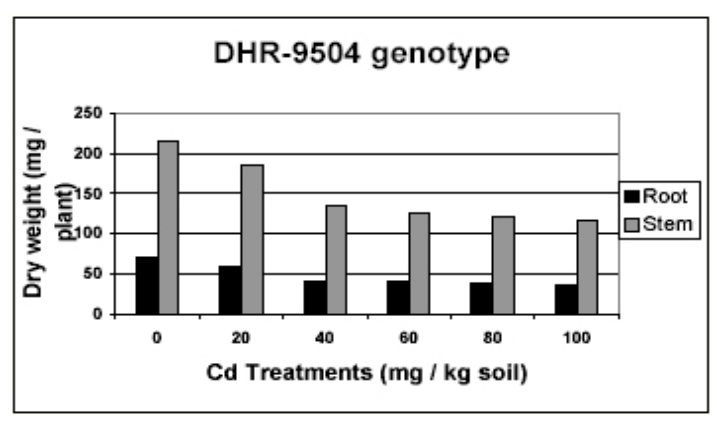

(B)

Figure 1A \& 1B. Effect of increasing Cd supply on stem and root dry weight of

Brassica juncea L. genotypes (Varuna and

DHR-9504). The data represent means \pm SD of three independent replications.

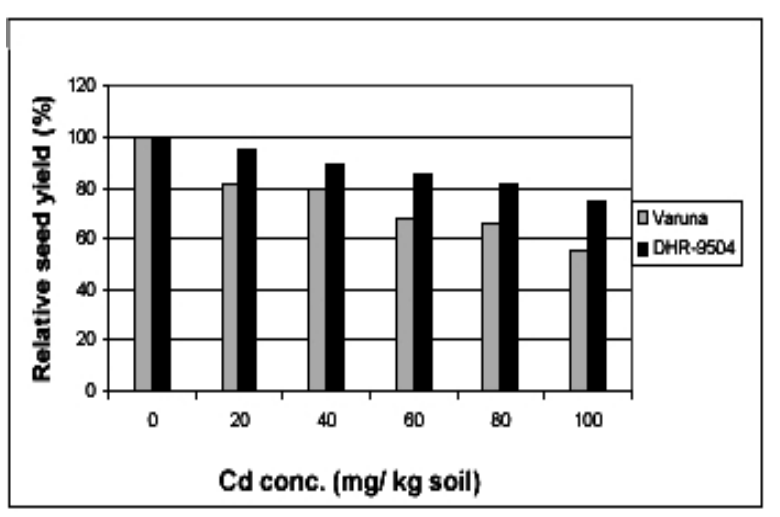

Figure 2. Relative seed yield of Brassica juncea L. genotypes (Varuna and DHR9504) as influenced by $\mathrm{Cd}$ application.
Significant differences among both genotypes and $\mathrm{Cd}$ treatments were noted concerning $\mathrm{Cd}$ accumulation. As expected, increasing $\mathrm{Cd}$ supply markedly enhanced the $\mathrm{Cd}$ concentration of plants (Table 1). An increase in $\mathrm{Cd}$ concentration of about 5 times in seeds, 7 times in stems and 9 times in roots was noted with an application of 20


(Table 1). Table 1 shows that $\mathrm{Cd}$ concentration in seeds of Brassica juncea plants varied from 3.2-68.5 $\mu \mathrm{g} \mathrm{g}^{-1}$ (with a mean of $31.85 \mu \mathrm{g} \mathrm{g}^{-1}$ ) and in the stem varied from 3.5 to $128 \mu \mathrm{g} \mathrm{g}^{-1}$ (with a mean of 51.65 $\mu \mathrm{g} \mathrm{g}^{-1}$ ) while that in the root varied from 7.2 to $316 \mu \mathrm{g} \mathrm{g}^{-1}$ (with a mean of $135.29 \mu \mathrm{g} \mathrm{g}^{-1}$ ). Table 1 also shows that $\mathrm{Cd}$ was accumulated in the roots in much higher amounts than in the stems, especially in the case of the genotype DHR-9504. For example, with 40 $\mathrm{mg} \mathrm{kg}{ }^{-1} \mathrm{Cd}$ supply, the $\mathrm{Cd}$ concentration in the roots was about 4 times higher than in the stems of genotype DHR-9504 and 2 times higher than in the stems of genotype Varuna.

\section{Discussion}

Genotypical variations in tolerance to $\mathrm{Cd}$ toxicity are well documented in the literature (Grant et al., 1998; Ozturk et al., 2003). Cd phytotoxicity was shown by growth retardation of Varuna and DHR-9504 (Figure 1). Marschner et al. (1988) also demonstrated $\mathrm{Cd}$ toxicity by growth retardation and leaf chlorosis of chinese cabbage in the early growing season. When compared to DHR-9504, Varuna showed higher sensitivity to $\mathrm{Cd}$ toxicity in this experiment (Figure 1A \& 1B). Patel et al. (1980) also reported that Varuna showed greater sensitivity to $\mathrm{Cd}$ toxicity as compared to other genotypes of Brassica 
Emir. J. Agric. Sci. 2004. 16 (2): 01-08

http://www.cfs.uaeu.ac.ae/research/ejas.html

juncea $\mathrm{L}$. this sensitivity might be due to higher $\mathrm{Cd}$ accumulation. Genotype Varuna had much higher $\mathrm{Cd}$ concentration in different plant parts indicating that it has better absorbing ability than DHR-9504 and has higher potential for removing $\mathrm{Cd}$ from moderately contaminated soil. Patel et al. (1980) and Sinha et al. (1981) also reported similar results. Singh and Nayyar (1994) reported that the relation between $\mathrm{Cd}$ in soil and $\mathrm{Cd}$ in plant is linear and the plant has an ability to exclude or accumulate large amounts of $\mathrm{Cd}$ at the higher $\mathrm{Cd}$ levels of soil. Simon (1998) also reported that $\mathrm{Cd}$ accumulated largely in roots and its concentration increased in shoots. High $\mathrm{Cd}$ contents in soils lead to a reduction in plant growth and dry matter yields. These findings are in close conformity with those of Haghiri (1973). The reduction in dry matter yield due to $\mathrm{Cd}$ application is in agreement with the findings of Lehoczky et al. (1996). Yield reductions in mustard plants have been attributed to the direct effect of higher $\mathrm{Cd}$ concentrations in plant tissue and not through an indirectly induced deficiency of other nutrients (Wilson, 1992). The results in Figure 1 show that the effect of $\mathrm{Cd}$ on stem and root growth is similar in both genotypes. In previous studies, Marschner et al. (1988) and Ozturk et al. (2003) also found that $\mathrm{Cd}$ supply reduced shoot and root dry matter production to a similar extent.

Table 1. Effect of increasing $\mathrm{Cd}$ supply on seed, stem and root $\mathrm{Cd}$ concentrations of two Brassica juncea L. (Indian mustard) genotypes (Varuna and DHR-9504). The data represent means \pm SD of three independent replications.

\begin{tabular}{|c|c|c|c|c|}
\hline \multirow{2}{*}{ Genotypes } & \multirow{2}{*}{$\begin{array}{l}\text { Cd supply } \\
\mathrm{mg} \mathrm{kg}^{-1} \text { soil }\end{array}$} & \multicolumn{3}{|c|}{ Cd concentration $\left(\mu \mathrm{g} \mathrm{g}^{-1}\right)$} \\
\hline & & Seed & Stem & Root \\
\hline \multirow{6}{*}{ Varuna } & 0 & $4.5 \pm 1$ & $7.0 \pm 1$ & $7.2 \pm 1$ \\
\hline & 20 & $22.0 \pm 1$ & $49.1 \pm 1$ & $65.2 \pm 1$ \\
\hline & 40 & $35.8 \pm 2$ & $52.0 \pm 1$ & $99.2 \pm 1$ \\
\hline & 60 & $44.5 \pm 3$ & $72.3 \pm 3$ & $114.1 \pm 3$ \\
\hline & 80 & $65.5 \pm 2$ & $98.0 \pm 2$ & $198.3 \pm 2$ \\
\hline & 100 & $68.5 \pm 4$ & $128.0 \pm 3$ & $298.4 \pm 2$ \\
\hline \multirow{6}{*}{ DHR-9504 } & 0 & $3.2 \pm 1$ & $3.5 \pm 1$ & $8.0 \pm 1$ \\
\hline & 20 & $16.3 \pm 2$ & $22.2 \pm 2$ & $72.3 \pm 4$ \\
\hline & 40 & $18.7 \pm 1$ & $26.5 \pm 1$ & $105.6 \pm 4$ \\
\hline & 60 & $23.3 \pm 2$ & $41.2 \pm 2$ & $125.4 \pm 4$ \\
\hline & 80 & $34.7 \pm$ & $253.7 \pm 3$ & $215.1 \pm 5$ \\
\hline & 100 & $45.2 \pm 4$ & $67.5 \pm 4$ & $316.0 \pm 6$ \\
\hline
\end{tabular}

Genotype DHR-9504 had significantly less uptake of Cd than genotype Varuna (Table 2). Most of the Cd taken up in Cd treated plants remained in the roots. Seed Cd uptake was lowest as compared to other plant parts in both the genotypes (DHR-9504 and Varuna). These results show that Varuna plants accumulate more Cd than DHR-9504. 
Table 2. Effect of increasing Cd supply on total Cd uptake in Varuna and DHR-9504 genotypes plants.

\begin{tabular}{llll}
\hline $\begin{array}{l}\text { Cd conc. } \\
\left(\mathbf{m g ~ k g}^{-1} \text { soil }\right)\end{array}$ & \multicolumn{2}{c}{$\begin{array}{c}\text { Absorbed Cd concentration } \\
\left(\boldsymbol{\mu g} \mathbf{~ p l a n t}^{-\mathbf{1}}\right)\end{array}$} \\
\hline & Varuna & DHR-9504 & Mean \\
\hline Control & 12 & 11 & 11.5 \\
20 & 190 & 138 & 164 \\
40 & 289 & 189 & 239 \\
60 & 307 & 237 & 272 \\
80 & 487 & 358 & 422 \\
100 & 689 & 499 & 594 \\
Mean & 329 & 238 & \\
\hline
\end{tabular}

Genotype DHR-9504 had significantly less uptake of Cd than genotype Varuna (Table 2). Bhatia et al. (1990) also reported similar results. It seems that plant mechanisms affecting the root uptake and shoot transport of $\mathrm{Cd}$ can also affect the expression of $\mathrm{Cd}$ toxicity in plants. This result is in agreement with that reported by (Dunbar et al., 2003). Wilson (1992) and Hall (2002) also stated that differences in root uptake and shoot accumulation of $\mathrm{Cd}$ can be an important factor in explaining genotypical variations in tolerance to $\mathrm{Cd}$ toxicity. Therefore, the selection of plant genotypes with high ability to repress root uptake and shoot transport of $\mathrm{Cd}$ is a reasonable approach to alleviate adverse effects of $\mathrm{Cd}$ toxicity in crop plants. It is important to know the different $\mathrm{Cd}$ toxicity resistances among genotypes and the potential of $\mathrm{Cd}$ accumulation as well as their physiological responses to Cd toxicity. The results in Table (1) show that DHR-9504 had a higher $\mathrm{Cd}$ concentration in the roots indicating that there is a more limited transport of $\mathrm{Cd}$ from the root system to the above ground plant parts than Varuna. These findings are in close conformity with those of Bhatia et al. (1990) and Patel et al. (1980). DHR-9504 has a better genetic ability to retain $\mathrm{Cd}$ in the roots, possibly by binding and sequestering it in the vacuole, due to presence of strong Cd-binding proteins, which may contribute to higher Cd tolerance in this genotype. The present results are also in agreement with the findings of Marschner et al. (1988). Hall (2002) and Ozturk et al. (2003) also reported the importance of Cdbinding proteins in the development of $\mathrm{Cd}$ tolerance in plants.

\section{Conclusion}

In conclusion, the results presented show the existence of genotypical variations in the tolerance to $\mathrm{Cd}$ toxicity among Brassica juncea L. (Indian mustard) genotypes. The differential tolerance to $\mathrm{Cd}$ toxicity in Brassica juncea L. was related to $\mathrm{Cd}$ concentrations in the different plant parts and the retention of $\mathrm{Cd}$ in the roots.

\section{References}

Adriano, D. C. 1986. Trace Elements in Terrestrial Environments, pp. 105-155. Springer - Verlag. 
Bhatia, P. K., K. K. Sharma, and S. K. Das. 1990. Studies on the effect of heavy metal stress on growth parameters of Brassica juncea (Indian mustard). J. Env. Biology. 10: 41-48.

Cataldo, D. D., T. R. Garland, R. E. Wildung. 1983. Cadmium uptake kinetics in intact soybean plants. Plant Physiol. 73: 844-848.

Clarkson, D. T., U. Lutge. 1989. III. Mineral nutrition: Divalent cations. Transport and compartmentation. Progress in Botany. 51: 93-112.

Deshveer, C. L. and A. Singh. 2003. Effectiveness of agro-chemicals on Indian mustard (Brassica juncea). Indian J. Agric. Sci. 73: 345-6

Dunbar, K. R., M. J. Mc. Laughlin and R. J. Reid. 2003. The uptake and partitioning of cadmium in two cultivars of potato (Solanum tuberosum L.). J. Experimental Botany 54: 349-354.

Fergusson, J. E. 1991. The heavy elements: chemistry, environmental impact and health effects. Pergamon Press, Oxford pp. 329-406.

Florijn, P. J. and M.L. Van Beusichem. 1993. Uptake and distribution of cadmium in maize inbred lines. Plant Soil, 150: 25-32.

Foy, C. D., R. L. Chaney and M. C. White. 1978. The physiology of metal toxicity in plants. Annual Review of Plant Physiology. 29: 511-66.

Grant C. A., W. T. Buckley, L. D. Bailey and F. Selles. 1998. Cadmium accumulation in crops. Can. J. Plant Sci. 78: 1-17.
Haag-Kerwer, A., J. S. Holger, S. Heiss, C. Walter and T. Rausch, 1999. Cadmium exposure in Brassica juncea causes a decline in transpiration rate and leaf expansion without effect on photosynthesis. Journal of Experimental Botany. 50: 1827-1835.

Haghiri, F. 1973. Cadmium uptake by plants. Indian J. Environ. Qual. 20:93-95.

Hall, J. L. 2002. Cellular mechanisms for heavy metal detoxification and tolerance. J. Exp. Botany. 53: 1-11.

Kabata-Pendias, A., H. Pendias. 1989. Trace Elements in Soils and Plants. Mir, Moscow, 152-186 (In Russion).

Kumar P., V. Duschenkov, H. Motto and I. Raskin. 1995. Phytoextraction: the use of plants to remove heavy metals from soils. Environ. Sci. and Tech. 29: 12321238 .

Lehoczky, E., I. Szabados, and P. Martha. 1996. Cadmium content of plants as affected by soil cadmium concentration. Commun. Soil Sci. Plant Anal. 27: 1765-77.

Marschner, A., G. R. Andersen, and J. K. Mason. 1988. Yield and uptake of cadmium and zinc by vegetables grown in soil polluted with heavy metals. Swed. J. Agric. Res. J. 8: 74-79.

Muramoto, S., H. Nishizaki and I. Aoyama. 1990. The critical levels and the maximum metal uptake for wheat and rice plants when applying metal oxides to soil. J. Environ Sci Health, Part B. 25 (2):273-80. 
NIAST (National Institute of Agricultural Science and Technology). 1988. Methods of Soil Chemical Analysis.

Nriagu, J. O. and J. M. Pacgana. 1988. Quantitative assessment of worldwide contamination of air, water and soils of trace metals. Nature 333: 134-9.

Ozturk, L., S. Eker, F. Ozkutlu. 2003. Effect of cadmium on growth and concentrations of cadmium, ascorbic acid and sulphydryl groups in durum wheat cultivars. Turk. J. Agric. For. 27: 161- 168.

Patel V. K., B. B. Rahi, C. S. Verma. 1980. Genotypic differences in effects of cadmium on yield and nutrient composition in Brassica plants. Agronomy Journal. 72: 45-7.

Patterson, O. 1977. Differences in cadmium uptake between plant species and cultivars. Swed. J. Agric. Res. J. 7: 21 24.

Sauer, J. D. 1993. Historical geography of crop plants - a select roster. CRC Press, Boca Raton, Florida.
Sheoran, I., V. K. Gupta, J. S. Laura, and R. Singh. 1991. Photosynthetic carbon fixation, translocation and metabolic levels in pigeonpea (Cajanus cajan) leaves exposed to excess cadmium. Indian J. Exp. Biol. 29: 857-61.

Simon, E. 1998. Cadmium accumulation and distribution in sunflower plants. J. Plant Nutr. 21: 341-52.

Singh, S. P. and V. K. Nayyar. 1994. Accumulation characteristics of cadmium in selected forage species. J. Ind. Soc. Soil Sci. 42:96-100.

Sinha C. G., M. L. Patil and H. K. Tripathi. 1981. Effect of cadmium on growth and concentrations of cadmium in Brassica juncea (Indian mustard) genotypes. Indian J. Agronomy. 26: 105-3.

Wilson, N. J. 1992. Accumulation of cadmium in crop plants and its consequences to human health. Agron. 51:

173-212. 